IZA DP No. 4487

\title{
Co-determination and Innovation
}

Kornelius Kraft

J örg Stank

Ralf Dewenter

October 2009 


\title{
Co-determination and Innovation
}

\author{
Kornelius Kraft \\ University of Dortmund, \\ ZEW and IZA
}

Jörg Stank

HOCHTIEF AG

\section{Ralf Dewenter}

University of IImenau

\section{Discussion Paper No. 4487 \\ October 2009}

\author{
IZA \\ P.O. Box 7240 \\ 53072 Bonn \\ Germany \\ Phone: +49-228-3894-0 \\ Fax: +49-228-3894-180 \\ E-mail: iza@iza.org
}

Any opinions expressed here are those of the author(s) and not those of IZA. Research published in this series may include views on policy, but the institute itself takes no institutional policy positions.

The Institute for the Study of Labor (IZA) in Bonn is a local and virtual international research center and a place of communication between science, politics and business. IZA is an independent nonprofit organization supported by Deutsche Post Foundation. The center is associated with the University of Bonn and offers a stimulating research environment through its international network, workshops and conferences, data service, project support, research visits and doctoral program. IZA engages in (i) original and internationally competitive research in all fields of labor economics, (ii) development of policy concepts, and (iii) dissemination of research results and concepts to the interested public.

IZA Discussion Papers often represent preliminary work and are circulated to encourage discussion. Citation of such a paper should account for its provisional character. A revised version may be available directly from the author. 
IZA Discussion Paper No. 4487

October 2009

\section{ABSTRACT}

\section{Co-determination and Innovation}

This paper examines the effect of the German co-determination law of 1976 (MitbestG) on the innovative activity of German firms. Co-determination applies to firms with 2000 employees or more. Data from 1971-1976 and 1981-1990 on 148 firms are used to compare the number of patents granted to co-determined firms before and after the introduction of the law. Several control variables are applied and in particular, in order to avoid a possible bias from specific effects of firm size, we compare the co-determined firms with others before and after 1976. The results do not support the view that co-determination slows down technological progress and reduces innovativeness.

JEL Classification: J5, L2, O3

Keywords: co-determination, innovation, patents

Corresponding author:

Kornelius Kraft

University of Dortmund

Department of Economics

Vogelpothsweg 87

D-44227 Dortmund

Germany

E-mail: kornelius.kraft@uni-dortmund.de 


\section{Introduction}

Since the introduction of the first co-determination laws in Germany in the fifties, their effects have been the subject of much discussion and controversy. Irrespective of this discussion, the laws have been extended, most recently as part of works constitution act in $2001^{1}$. Furthermore, the European Union is thinking about introducing similar rules at a European level. Although the European regulations will have less far-reaching effects on workers' rights than the German ones, the German experience should be of interest for policy making.

The expected effects of co-determination are discussed quite intensively and with very distinct views. An important issue arising during the discussion about the effects of codetermination is technological progress. It is frequently supposed that at the very least codetermination will increase the time needed to reach decisions ${ }^{2}$. This may well negatively affect the introduction time of process and product innovations. Other, non- co-determined firms might react more flexibly and the larger co-determined firms would in this case lose innovative potential.

However, a direct effect of co-determination may also exist as workers might oppose the introduction of process innovations, if they fear negative effects on employment. Product innovations might also be affected, since product innovations go hand in hand with a reorganization of work and the workers will presumably dislike any new organization. On the other hand, it is frequently argued that co-determination improves information management in a firm, and improved information will most probably have a positive impact on technological progress. In our view, it remains an empirical question as to whether co-determination has a negative or positive effect on innovation.

In contrast to the intense theoretical discussion and the research on the effects of works councils, very few empirical studies exist which examine the effects of codetermination. The purpose of this paper is to study the effects of the German codetermination law of 1976 on technological progress, estimated at firm level. Our measure for technological progress is the number of patents granted to a particular company. The main difference to earlier research (Kraft and Stank 2004) is the inclusion of the theoretical model and the application of a superior econometric methodology for count data. The empirical test takes account of the panel structure of the data and uses standard errors, which are adjusted for clustering.

\footnotetext{
${ }^{1}$ Works Constitution Act Revision of 22.6.2001.

${ }^{2}$ Representative for this view is von Weizsäcker (1984).
} 


\section{Institutional Facts}

Aside from countries such as the Netherlands, Luxembourg or Denmark, Germany has the furthest reaching regulations concerning worker co-determination. The two most important acts are the works constitution act and the co-determination law. The workers rights at plant level are determined by the works constitution act from 1972 (BetrVG 1972). According to this law, in firms with five or more workers, the employees can ask for the introduction of a works council. The works council has co-determination rights on "hiring and firing" decisions, on technological change and many other issues. The co-determination rights depend in part on the size of the plant. For example, if the plant has 100 employees or more, the management is required to inform the works council about major economic developments. The works councils are not allowed to negotiate about wages, but there may be indirect ways of influencing the wage level.

A second size effect is determined by the fact that many small firms do not have a works council at all and that the probability of its existence strictly increases with the number of employees. In firms with less than 20 employees only $5 \%$ have a works council. However, 99\% of the larger plants with 1000 or more employees do have a works council ${ }^{3}$.

In contrast to the works constitution act, the co-determination law is put into practice in all firms where it can be applied. It is based on three different laws. The coal and mining industry has had full parity co-determination since $1951^{4}$. The most significant regulation is that on the supervisory board, $50 \%$ of the seats go to the workers (in the case of a conflict, an external member who is said to be neutral decides). In addition, the member of the top management who is responsible for the employees (personal director) must be approved by the workers (or their representatives).

The first version of the works constitution act was passed in 1952. Aside from the rights discussed above, there is also a co-determination right according to this law. In firms with 500 to 2000 employees, workers are entitled to one third of the seats (and votes) on the supervisory board.

The German two tier system of firm leaderships distinguishes between the board of directors (Vorstand) and the supervisory board. The board of directors is responsible for the day to day business and meets several times per months. In contrast the task of the supervisory board is control of the top management, information exchange and approval of all

\footnotetext{
${ }^{3}$ See Addison, Schnabel and Wagner (2000), Niedenhoff (1997).

${ }^{4}$ The "Montanmitbestimmungsgesetz" in Germany is thereby the oldest still existing law of this kind.
} 
important decisions. The supervisory board meets less frequently than the board of directors, in many cases it is four times per year. During these meetings all important questions concerning business policy and company strategy are discussed.

The third co-determination law and perhaps the one with the most important effects on the economy as a whole, is the co-determination law of 1976 (MitbestG). It applies to firms with at least 2000 employees. In such companies, the employees have the right to a 50\% representation on the supervisory board. However, in contrast to the regulations in the coal and mining industry, in case of a conflict the chairman of the supervisory board, who is determined by the capital owners, has two votes. Hence in this case the expression "quasiparity" is more appropriate than speaking of parity co-determination. Another difference with respect to the coal and mining industry is that the appointment of the personal director does not require the approval of the employees.

One might ask the general question what kind of authorizations a supervisory board has and which topics are at all discussed at the meetings. The most important issue is presumably the appointment of the board of directors and of the CEO. A subcommittee of the supervisory board is also responsible for remuneration including determination of fixed and flexible components.

In general, the supervisory board must be informed about any important business decision and must approve all issues of significant relevance for the company. Usually a list of important operations which require approval is defined ("zustimmungspflichtige Geschäfte”). This list can be divided into decisions concerning the current situation and strategic decisions. The report on the present situation covers, among other things, market conditions (sales, market share), employment (number of jobs, costs, working time, productivity, turnover), production (production volume, inventories, material costs, capacity), finance (debt, equity, leverage, investment), and profitability (cash flow, profits, return on investment, liquidity).

Strategic decisions with a medium to long-term relevance encompass market development (technology, general trends in the main industry, the economy and foreign markets), medium to long-term corporate planning (strategy, research and development, human resources, production, finance, forecasts concerning sales volume and profits) ${ }^{5}$. Sick, Köstler and Mielke (2005, 39) also list internal as well as external research and development expenditures among the list of operations that need approval. The German Stock Companies Act stipulates in $\S 289$ that the directors have to inform the members of the supervisory board

\footnotetext{
${ }^{5}$ This enumeration follows Theisen $(1996,92)$.
} 
about general business trends. In particular, transactions which have taken place after the end of the accounting year, the expected development of the company, and research and development expenditures have to be reported. ${ }^{6}$ Sometimes even the selling or acquisition of patents is considered as an essential operation. ${ }^{7}$ Hence innovation policy is (among other topics) an issue that must be dealt with during the meetings of the supervisory board and the R\&D policy must be approved by the members. Jürgens and Lippert (2005) argue that supervisory boards not only approve innovation projects (or reject them) in many cases, but encourage research on concrete innovations.

It might be the case that the supervisory boards have the power to discuss and decide on innovation policy, but for some reason this right may not be executed. Fischer and Beckmann $(2007,85)$ explicitly explore the topics on which information is provided for the members of the supervisory boards. Information concerning R\&D is distributed in $31.0 \%$ of all cases on a monthly basis, in $21.2 \%$ quarterly and in $22.1 \%$ biannually. In $10.6 \%$ the members of the supervisory boards report not to have received any information and in $15.0 \%$ of all cases no answers are given. Fischer and Beckman $(2007,115)$ also investigate the use of the information given. Accordingly the information is in the first place of help to control the top management but is also used as a measure to control the realization of decisions of the supervisory boards. Hence codetermination may well affect innovative activity.

The effects of German co-determination laws have been discussed controversially since their introduction in the 1950s. Irrespectively of this controversy, most recently the laws have been extended on national level and also the EU aims at introducing similar rules. Although the European regulations will have less far-reaching effects on workers' rights the German experience should be of interest.

One important topic connected with co-determination is innovativeness. Technical progress might be affected in many ways and one effect could simply be exerted by the requirement to discuss issues with the employees' representatives on the supervisory boards so that decision making takes longer. This in turn might have an impact on the time necessary to introduce product and process innovations.

Moreover workers are likely to oppose the introduction of process innovations directly, if they fear negative effects on employment. This might not only affect process innovations, but also product innovations, as these are frequently related to reorganizations of work, which are presumably disliked by workers. Thus workers' representatives on the supervisory boards could aim at stopping or at least delaying innovative projects.

\footnotetext{
${ }^{6}$ Potthoff and Trescher (1993, 134).
} 
In contrast the proponents of codetermination argue that co-determination improves information processing, and improved information could positively affect technological progress $^{8}$. Hence a priori it is unclear whether co-determination has a negative or positive effect on innovation and therefore this issue has to be analyzed empirically. However despite the political relevance and the many theoretical contributions, empirical analysis on the effects of co-determination is rare. For this reason, our contribution is an examination of the effects of the German co-determination law of 1976 on innovativeness. We use the number of patents granted to a particular company as a measure of technical progress.

It is possible that the co-determination law has no effect at all, since in the case of conflict the capital owners still have the majority of the votes. However, the practice of codetermination shows that nearly all decisions are reached unanimously and thus the board tries to reach a consensus. The employees might ask for the approval of one issue as “compensation”, when the interests of the employees are affected.

In our view, there appear to be two main differences between co-determination based on the works council and the supervisory board: Firstly, the works council does not exist in many firms and the decision of the workforce to ask for it is unlikely to be accidental. This means that firms with a works council must not be representative for the whole economy, but subject to a selection process and research must take this into account. On the one hand firms with a works council might be those with particularly bad industrial relations. On the other hand they might, however, be those with a stable workforce, low turnover rates, highly qualified workers, as these workers are interested in the firm in question and take on responsibility. In contrast to the introduction of a works council the co-determination law is mandatory. There is no choice and therefore the effects of this kind of regulation is not “contaminated” by selection effects of one kind or another.

Secondly, the works council is responsible for social affairs and industrial relations and here it has some powerful rights, but the "hard" economic topics like investment and so on are still within the responsibility of top management. The works councils are informed only concerning economic developments (if the plant has 100 or more employees) but that is all. In contrast, the co-determination law requires a participation of the workers on all essential decisions at the highest level within the firm. The most important right is perhaps the appointment of the top management and the renewal or non-renewal of their contracts.

\footnotetext{
${ }^{7}$ Gerum, E. (2007, 270).

${ }^{8}$ Consider for example the position of the metal working union (IG Metall 2004) expressed in the publication "Die Innovation der Innovationspolitik",
} 
Moreover, investment or dismissals above a certain limit have to be approved by the supervisory board. Hence, this is much more than information.

In practice there is a considerable overlap between the works council members and the members of the supervisory board appointed by the employees. While considerable empirical research on the effects of the works council exists, there are very few results on codetermination (see e.g. Kraft and Stank, 2004 as well as FitzRoy and Kraft 2005 for the case of co-determination and Addison, Schnabel and Wagner 2001 as a representative study on the effects of works councils on innovation). Given the general relevance of the question as to how mandatory co-determination affects firm performance in the light of the controversial hypotheses and the EU's interest in introducing a similar scheme at European level, the analysis should find some attention.

\section{Theoretical Considerations}

\subsection{General Discussion}

The theoretical discussion is quite controversial and apparently also affected by ideological positions. In the first step, one might ask whether co-determination will have any effect. As mentioned above, in the case of a conflict the capital owners still have the majority of the votes. With this in mind, why should co-determination have any effect at all?

The commission "Mitbestimmung" also discusses this point and argues that the overwhelming majority of all decisions are unanimous. The supervisory board attempts to reach decisions which are acceptable to all members. Consensus is perhaps not a bad idea if decisions have to be reached in the company, and the workforce will show improved motivation if they recognize that their interests are also being taken into account. (Final report of the Commission Co-determination Chapter 8, Nr. 2 and Nr. 5). Unanimous decisions will be accepted more easily by the employees as being fair, and equity considerations might well have their affect productivity (cf. for example in a different context Akerlof and Yellen 1990).

However, even if the result is a cooperative one, decisions will certainly take longer if a consensus is needed; compromises will in part limit the interests of the capital owners and flexibility is necessarily reduced. It is clearly possible that such an environment reduces the innovativeness of an organization. Co-determination may well lead to a tendency to maintain the status quo in order to avoid any conflict.

Concerning mandatory co-determination, there are two schools in economics with very different opinions. According to the property rights theory, decision rights must be concentrated among those persons who bear the risk (cf. among others Furubotn 1978, 
Alchian 1984). In a market economy these are still the capital owners. Workers are assumed to have a different time horizon, at least not the infinite horizon of maximizing the present value of the firm. According to this argument, long-term investments are not in the interest of the workforce, and - given the long lags between R\&D and returns on these expenditures ${ }^{9}$ this is a point against innovative activity. A technological immobility and an overemphasis on employment related aspects are thus expected by some people (Final report of the Commission Co-determination, Chapter 8). Von Weizsäcker (1983, p.146) also shares this opinion and explicitly considers co-determination on the supervisory board and its effect on innovativeness (our translation):

"The ability of an enterprise to react flexibly to changed conditions, to become aware of innovation possibilities, to weight risks against opportunities is affected very strongly by its internal organization and decision structure. [...] Co-determination divides the decision rights in the enterprise and therefore in fact leads to a reduction of its decision and co-ordination strength."

Members of the commission co-determination also consider this problem (Final Report of the Commission Co-determination, Chapter 8, Nr. 20, our translation):

"Such an organisational structure has the disadvantage not only of depending on time-consuming consultation processes - the working of which must be cultivated carefully - but it is also inclined to decide rather conservatively."

The property rights theory, in general, dislikes intervention by government into the decision rights of firms. The argument is that if it were efficient, then it would emerge in an evolutionary way by itself (see among others Jensen and Meckling 1979). Clearly this argument is relevant, although there are situations possible, where the market mechanism does not work. Additional support for a skeptical view concerning this law might come from a political-economic perspective. The co-determination law of 1976 was passed during the SPD/FDP (social democrats and liberals) government. Traditionally, the social democrats are associated with unions and one could argue that this government introduced this law in order to do the unions a favor, even if the whole economy does not benefit from it. This has some logic, if one believes in rent-seeking. In contrast to the view of the opponents of codetermination the participation theorists are less optimistic regarding the outcome of market

\footnotetext{
${ }^{9}$ Cf. Ravenscraft and Scherer (1984) for an investigation on this question.
} 
processes in general. In particular they emphasize the role of market imperfections, which impede realization of a first best solution ${ }^{10}$. One possible problem is imperfect information concerning the work process and organization. Co-determination is by construction an institution, which fosters information exchange. The proponents of such an institutional setting argue that the implementation of this institution enables the use of information from employees, which would otherwise be lost. Furthermore, it will lead to a more cooperative solution, and the conflict between capital owners and the workers is reduced if not solved. According to this view, productivity will increase as a result, and such firms will be successful on the market ${ }^{11}$.

It is also argued that codetermination serves as a control mechanism against management opportunism. Managers may well have their own interests, which must not necessarily coincide with those of the capital owners. Workers and their representatives may in many cases have better information on the behavior of the managers than the capital owners, in particular if capital shares are widely distributed. The worker representatives can exert pressure on the top management to follow the aims of the company and not their own ones. Growth might be limited to a non-risky expansion path and investment projects with uncertain returns might be cancelled.

Finegold and Soscice (1988) discuss the way how firms meet declining demand. In countries like Germany companies use internal restructuring with an emphasis on product innovation and internal training activities. The high investment in human capital along with high employment protection lead to internal flexibility with not much labor adjustment, but engagement of the workforce for the company including support for innovation. This is also realized by advices of the members of the supervisory board.

Freeman and Lazear (1995) offer a number of arguments as to why the market solution may be inefficient. They state that any participation rights are connected with redistribution and that it is this redistribution process which impedes voluntary agreement. The authors start from the assumption that the organization has a rent $\mathrm{R}$, which depends on the bargaining power of the workers' $x$. The rent first rises and then declines in $x$. The share $\tau(x)$ of the rent goes to the workers and this share also depends on $\mathrm{x}$, with an increasing share if $\mathrm{x}$ rises.

The firm maximizes:

$$
(1-\tau(x)) R(x) \quad \text { and this implies }
$$

\footnotetext{
${ }^{10} \mathrm{Cf}$. Smith (1991) for a discussion of the arguments of the participation theorists.
} 


$$
\underbrace{-\tau^{\prime}(x) R(x)}_{<0}+\underbrace{(1-\tau(x)) R^{\prime}(x)}_{>0}=0 .
$$

Therefore there is not enough co-determination if rent maximization is the aim.

On the other hand the incentives of the workers are:

$$
U=\tau(x) R(x)
$$

and this in turn yields:

$$
U^{\prime}=\underbrace{\tau^{\prime}(x) R(x)}_{>0}+\underbrace{\tau R^{\prime}(x)}_{<0}=0
$$

Then we have too much co-determination if again the rent should be maximized $\left(R^{\prime}(x)=0\right)$. The commission co-determination (final report, Ch. 3 and 8) supports the view of productivity enhancing effects of co-determination (our translation):

"Despite all the difficulty of an accurate measurement, many critics of codetermination also accept the peace-keeping and productive effects of consent and cooperation, which are supported by co-determination rights, in principle.”

Finally, it might be argued that capital owners are unwilling by principle to share their decision rights, simply because they like their independence. This may or may not be efficient, but that is not the reason for them to behave in this way.

Theory is unable to answer our question and it remains a task for empirical research. Therefore, in this respect, we follow Junkes and Sadowski (1999, S.63, our translation):

"Theoretically there is (still) no generally accepted answer to the question of the economic effects of laws of co-determination. Rather, it appears necessary to look for empirically measurable effects concerning supervisory board co-determination laws in Germany."

\subsection{A Model on Co-determination and Innovation}

\footnotetext{
${ }^{11}$ In a different but related context Finegold and Soscice (1988) argue that the involvement of unions in curriculum development of training courses is one reason for the better qualification of worker in such countries like Germany and Sweden in comparison to the UK.
} 
We enlarge a model on co-determination originally developed by Kraft $(1998,2001)$. The main modification is the extension by considering $R \& D$ expenditures ${ }^{12}$. As reviewed above since the effects of co-determination are quite controversy discussed. An important issue arising during the discussion about the effects of co-determination is technological progress. It is frequently supposed that at the very least co-determination will increase the time needed to reach decisions. This may well negatively affect the introduction time of process and product innovations. Other, non- co-determined firms might react more flexibly and the larger codetermined firms would in this case lose innovative potential.

However, a direct effect of co-determination may also exist as workers might oppose the introduction of process innovations, if they fear negative effects on employment. Product innovations might also be affected, since product innovations go hand in hand with a reorganization of work and the workers will presumably dislike any new organization. On the other hand, it is frequently argued that co-determination improves information management in a firm, and improved information will most probably have a positive impact on technological progress. In our view, it remains an empirical question as to whether co-determination has a negative or positive effect on innovation.

Only very few empirical studies exist which examine the effects of co-determination. The purpose of this paper therefore is to study the effects of the German co-determination law of 1976 on technological progress, using firm level data. To measure technological progress we use the number of patents granted to a particular company. However, in contrast to earlier research (see, e.g., Kraft and Stank 2004) both a theoretical model as well as a superior econometric methodology for count data is applied.

In contrast to Kraft (2001) we are only able to solve the model for rather simple situations: we assume a duopoly with symmetric bargaining power and the firms either bargain or maximize profits without co-determination, but we do not consider asymmetric solutions with one bargainer and one profit-maximizer. However, we include product differentiation, which was omitted in the earlier studies.

\section{Bargaining on Employment in Contrast to Profit Maximization}

The purpose of this section is a simple comparison between bargaining over employment and profit maximization with respect to the incentives to perform $R \& D$. The starting point of the theoretical analysis is the assumption that wages are determined by an exogenous process at industry level, which is consistent with the German institutional setting. Exogenous means not

\footnotetext{
${ }^{12} \mathrm{Cf}$. for an alternative approach to model the effect of codetermination on R\&D Granero (2006). His model is
} 
influenced at the individual firm level, as is the case if wages are negotiated at the economywide level.

In our model decisions are reached by negotiations between the employees and the firm owner. We are only able to solve the model for symmetric bargaining power. Hence, this is a difference to Kraft $(1998,2001)$.

Employment is determined at the level of the individual firm. The bargaining solution will be compared to the situation where employment is fixed by the employer alone. Bargaining takes place between the firm owner(s) and representatives of the employees. This might be the union or any other representative body. Industry unions, on the other hand, are not considered. This scenario is consistent, for example, with German co-determination, where representatives of the firm's employees decide. In most cases, these are members of the German unions, but this is no precondition for such a task.

We assume a duopoly situation with Cournot-Nash optimization. As Booth $(1995,95)$ observes: "It appears to be an empirical regularity that imperfections in the labor market are correlated with imperfections in the product market“. Unions will only be able to negotiate employment (or wage) increases above the competitive level if there is some rent or surplus to be distributed. Thus it does not appear to be a purely academic exercise to investigate bargaining power by unions (or other workers' representatives institutions) within the context of oligopoly. The two firms 1 and 2 produce similar products. Demand is determined according to a negatively sloped inverse demand curve of this particular shape:

$$
P=d-b\left(q_{i}+\theta q_{j}\right)
$$

Of course $P$ stands for the price and $q_{i}\left(q_{j}\right)$ is output by firm 1 (firm 2). The slope of the demand curve is determined by the parameter $b$ and in contrast to earlier work we include here product differentiation by the term $0 \leq \theta \leq 1$. If $\theta=0$ we have two monopolies and with $\theta=1$ the products are homogenous.

We start with bargaining, assuming the bargaining process to be represented by the well-known Nash-bargaining solution. As shown by Binmore, Rubinstein and Wolinsky (1986), the simple Nash solution may still be used as the equilibrium outcome of a sequence of non-cooperative moves. Thus this specification is more general than it initially appears.

The union has utility $Z(w, L)$ which depends positively on both, employment $L$ and wages. Specifically following e.g. McDonald and Solow (1981) or Dowrick (1990), we set: 


$$
Z(w, L)=L U(w)
$$

where $U$ is a differentiable utility function. Given that the wage is determined elsewhere, only employment remains to be maximized.

R\&D expenditures are considered similarly to a specification proposed by d'Aspremont and Jacquemin (1988) and applied by many others (see, e.g., Henriques 1990, Suzumura 1992 de Bondt and Henriques 1995). According to them the innovative activities (called $x$ ) reduce production costs and are therefore used for process innovations. If no R\&D takes place, the production costs are c, (ignoring for the moment w). The costs of innovative activity are $\gamma \frac{x^{2}}{2}$ and the term $\gamma$ is called efficiency parameter. The profit equation in this case is:

$$
\max \pi_{i}=\left[d-\left(q_{i}+\theta q_{j}\right)-w-c+x\right] q_{i}-\gamma \frac{x^{2}}{2}
$$

The variable costs accordingly are $C_{i}=(c-x+w) q_{i}$. The second order conditions require that $\gamma>2 /(\theta+2)^{2}$ and we assume that this condition is satisfied.

As said before, usually this specification is applied to process innovation, but in our case an alternative interpretation as product innovation seems to be more useful ${ }^{13}$. In this case we interpret $R \& D$ expenditures as measures to improve the quality of a particular good. Now $\mathrm{x}$ shifts the demand curve to the right and we specify this situation as an increase of $d$. The profit equation is then

$$
\max \pi_{i}=\left[d+x-\left(q_{i}+\theta q_{j}\right)-w-c\right] q_{i}-\gamma \frac{x^{2}}{2}
$$

which is exactly the same as above ${ }^{14}$.

In order to proceed, a concrete and extremely simple production function is applied: $\mathrm{q}=L$ (cf. for a similar assumption Dowrick 1989, 1990 and Bughin 1995). Now the bargaining as well as the profit maximization process is easily described. We use the Nash-bargaining solution. Bargaining is represented by the following product in the case of symmetric bargaining power:

\footnotetext{
${ }^{13}$ We apply a very specific production function as only labor is considered. In order to interprete $\mathrm{x}$ as $\mathrm{R} \& \mathrm{D}$ expenditures that reduce production costs, we offer the following interpretation: Aside of labor a second input is needed, which is however normalized to one unit per worker. Part of the other input however depreciates. Depreciation is now endogenously determined. If more expenditures for R\&D take place, the "other" input can be used for more time periods and less depreciation costs arise. Therefore with higher x production costs are lower.

${ }^{14}$ In principle, we do not need c, and all results are similar, if c is omitted.
} 


$$
\max V=\left[\left[d-\left(q_{i}+\theta q_{j}\right)-w-c+x\right] q_{i}-\gamma \frac{x^{2}}{2}\right]\left[\mathrm{U}(\mathrm{w}) q_{1}\right]
$$

The threat points have been set to zero for both parties following a popular simplification found, among others, in Fershtman (1985), Bughin (1995) or Booth and Chatterji (1995). This seems to be defensible for the employer, as no capital and thus sunk costs are considered. On the other hand it implies that other employment opportunities outside of this particular industry are disregarded.

It is only bargained on employment, not on $x$. The model becomes trivial there if it is also bargaining about $\mathrm{R} \& \mathrm{D}$, as the employees always have an incentive to increase $\mathrm{x}$, as output then rises. After taking the logarithm this equation is maximized with respect to $q_{i}$, which leads to the reaction function:

$$
q_{i b}=\frac{4}{3} \frac{\gamma\left(d-\theta q_{j}-w-c\right)}{2 \gamma-1}
$$

\section{Symmetric Bargaining or Profit-Maximizing Firms}

As mentioned above, we are only able to solve the model for symmetric bargaining or symmetric profit maximization. The asymmetric solutions with one firm bargaining and one firm maximizing profits are too complicated for an explicit solution with two endogenous variables $q$ and $x$.

If both firms are bargainers and behave according to Cournot-Nash they end up with the following output level:

$$
q_{i b}=4 \frac{\gamma \cdot(d-w-c)}{4 \gamma \cdot \theta+6 \gamma-3} ; i=1,2
$$

The firms choose optimal employment (output) as well as optimal x simultaneously. It is then solved for $\mathrm{x}$ :

$$
x_{i b}=4 \frac{(d-w-c)}{4 \gamma \cdot \theta+6 \gamma-3} ; i=1,2
$$

Hence the resulting profits for each firm are: 


$$
\pi_{i b}=4 \gamma(d-w-c)^{2} \cdot \frac{(2 \gamma-1)}{(4 \gamma \cdot \theta+6 \gamma-3)^{2}} ; i=1,2
$$

In order to compare the bargaining outcome with the 'traditionally' assumed employment determination, we next consider profit maximization without any restriction $(\beta=1)$. The firm is simply maximizing $\pi=\left(d-b\left(q_{i}+\theta q_{j}\right)-w\right) q_{i}$, which yields the following reaction function:

$$
q_{i P}=\frac{\gamma\left(d-\theta q_{j}-w-c\right)}{2 \gamma-1} ; \mathrm{i} \neq \mathrm{j} .
$$

Output and expenditures for $x$ are in this case:

$$
q_{i P}=\frac{\gamma(d-w-c)}{\gamma \cdot \theta+2 \gamma-1} \quad \text { and }
$$

$$
x_{i P}=\frac{(d-w-c)}{\gamma \cdot \theta+2 \gamma-1}
$$

and profits will be:

$$
\pi_{i P}=\frac{1}{2} \cdot(d-w-c)^{2} \cdot(2 \gamma-1) \cdot \frac{\gamma}{(2 \gamma+\gamma \cdot \theta-1)^{2}}
$$

\section{Comparison of R\&D Expenditures, Output Levels and Profits}

In a further step we want to compare profits, $R \& D$ expenditures and output levels of bargainers and profit maximizers. The comparison is somewhat easier if the ratio is considered instead of the difference. Dividing equations (5) and (9) and in a second step (4) and (8) we get:

$$
\frac{q_{i b}}{q_{i P}}=\frac{x_{i b}}{x_{i P}}=4 \cdot \frac{\gamma \cdot \theta+2 \gamma-1}{4 \gamma \cdot \theta+6 \gamma-3} .
$$


It can be shown that - independent of the value of $\theta$ - at $\gamma=0.5$ the investment in $\mathrm{x}$ and the output are the same for the bargainer and the profit maximizer. As one can see from equations (6) and (10), values of $\gamma<0.5$ are irrelevant because otherwise the profit would be negative. For values of $\gamma$ larger than 0.5 the bargainers' innovative activity and output is always larger than that of the profit maximizers. We find this is a surprising result.

The comparison between the different profits is slightly more complicated. From equations (6) and (10) we get:

$$
\frac{\Pi_{i b}}{\Pi_{i P}}=8 \cdot \frac{(\gamma \cdot \theta+2 \gamma-1)^{2}}{(4 \gamma \cdot \theta+6 \gamma-3)^{2}}
$$

In this case there are many different combinations of $\gamma$ and $\theta$ possible, which lead to equal profits for bargainer and profit maximizer. But again, it can be shown that for values of $\gamma>0.5$ the profit of the profit maximizer is higher. For values lower than 0.5 , combinations of $\gamma$ and $\theta$ exist where the bargainer realizes a higher profit but these situations are irrelevant. As mentioned above, the profit for the bargainer and the profit maximizer is only positive if $\gamma>0.5$ and so if a profit is made at all, the profit maximizers realize the larger ones.

Hence it is quite likely that the bargaining firm has higher expenditures for $R \& D$ even if $R \& D$ is not the subject of negotiations. The reason for this is that the bargaining firm has an incentive for firm size, as long as this is connected with employment. Both process and product innovation have a positive impact on size and this determines the result.

\section{Empirical Study}

\subsection{Earlier Research}

To the best of our knowledge, there has been no empirical study concerning the effects of codetermination on innovativeness. However, there are three kinds of related research: 1) Studies on the effects of works councils in Germany, 2) studies on the impact of unions on innovative activity for the US and Great Britain and 3) research on the impact of codetermination on productivity and profitability of German firms.

As explained earlier, works councils are not mandatory and therefore one way to estimate the effect of a works council is the comparison of firms with and without one. The 
first study on works councils and innovation is by FitzRoy and Kraft (1990). They use a small sample of German firms, interact the existence of a works council with the rate of unionization and find a negative impact of this variable for innovation. Addison, Schnabel and Wagner conduct a number of empirical studies on innovation. Addison, Schnabel and Wagner (2001) is a recent summary of their research results and they find no significant effect of the existence of works councils on innovation.

Many theoretical studies on unions point to a negative impact of unionization because unions raise wages and this is financed by appropriating the quasi-rents earned on capital ${ }^{15}$. This acts like a tax and will therefore increase the costs of reduced investments. This is a problem particularly for intangible investments like R\&D and a classical "hold-up” problem arises. A difference between the effect of a union and co-determination might be that in Germany wages are determined elsewhere but not by the supervisory board. Wage councils may have an effect on wages but the supervisory board does not discuss remuneration (with the notable exception of the salaries of the directors).

There are many studies from the US which usually report a negative impact of unionization on innovation. Examples (among others) are Conolly, Hirsch and Hirschey (1986), or Fallick and Hasset (1999) on investment. A recent study for Great Britain (Menezes-Filho, Ulph and van Reenen 1998), however, finds that unions can have positive effects in some cases. A negative impact is only estimated if union density is very high or unions bargain only about wages.

Svejnar (1982) uses industry data in order to estimate the productivity effect of the Works Constitution Act of 1952, the extension in 1972 and the co-determination act of 1951. He finds a significant decrease of productivity after the introduction of the extended Works Constitution Act of 1972. However because of the small magnitude, in his view a clear interpretation is impossible.

The first study on co-determination witch uses firm data is carried out by FitzRoy and Kraft (1993) and found a negative impact on productivity for a small sample and only one year before and one after introduction of the co-determination law. FitzRoy and Kraft (2004) show that in a panel of (West) German firms, the change from one third parity to full parity of labor representation on the supervisory board (after the Co-determination Act of 1976) resulted in a small but statistically significant increase in total factor productivity. On the other hand, Gorton and Schmid (2000, 2004) find a negative effect of parity co-determination

\footnotetext{
${ }^{15}$ A well-known example for this view is Grout (1984).
} 
on equity returns and other profit measures in cross sections of German firms before and after unification.

\subsection{Basics of Our Empirical Study}

Our empirical study concentrates on the effect of co-determination on technical progress. The basis of our study is a sample of 148 German stock companies, of which 61 are codetermined. The criterion for selection of the other firms is simply the availability of the necessary data from companies that publish this information for the years in question. We include all information that is available to us. Our variable indicating innovativeness is the number of patents. Clearly alternative measures, such as R\&D employment (see e.g. Scherer, 1965) R\&D expenditures (see e.g., Grabowski and Mueller, 1978; Ben-Zion, 1984; Griliches, 1986), the numbers of commercialized inventions (see Blundell et al., 1999, Acs and Audretsch, 1993) would also be very useful in order to test the robustness of our results. However, since German stock companies are not required to publish information on $\mathrm{R} \& \mathrm{D}$ our analysis is restricted to patents.

\section{Patents as an Indicator for Innovative Activity}

At least in highly industrialized countries, technological innovation is seen as a key input for long term employment and growth ${ }^{16}$ (along with human capital investment) and therefore the understanding of the economic process that leads to process and product innovation is of great interest. However, the identification of innovative output is not easily done, as there is not a single undisputed variable which measures innovation success completely. R\&D is clearly an input to the innovation production, but it may also be wasted if nothing gets invented. It is possible that co-determination does not lead to less R\&D expenditures, but that these activities are not connected with a proportional research output because other, smaller and not co-determined firms are faster and get their patents granted. Sales volume realized by newly developed products is only an indicator for product and not process innovation and need not necessarily reflect innovative output, as newly developed products may be the result of spillover effects or imitation.

Patents are a very frequently used indicator for invention output, but the use of this variable has been criticised by several authors (e.g. Griliches, Pakes and Hall 1986, Griliches 1990). It is pointed out that patents do not fully represent all of the innovative output of R\&D because only a part of the knowledge-creating process leads to patentable inventions. Even if

\footnotetext{
${ }^{16}$ The importance of innovation is reflected, for example, in the new growth theory, cf. for textbook expositions Aghion and Howitt (1998) as well as Barro and Sala-i-Marin (2004).
} 
the knowledge is patentable, inventors may decide not to do it because of the costs associated with patenting and/or because they rely on other methods to protect intellectual property. Among others, Cohen, Nelson and Walsh (2000) point out that firms frequently follow other strategies, e.g. secrecy or lead time ahead of competitors.

Despite its shortcomings, patent data is the most frequently used innovation output indicator, e.g. applied for comparing the innovative success of countries. One reason for its popularity is the easy access, as patent applications are systematically recorded by national patent offices. However, it should not be overlooked that most of the crucial inventions of the last century were indeed patented.

At least since the mid-1960s the relationship between firms' R\&D expenditures and patent applications has been analysed (see,for example, Scherer, 1965; Mueller, 1966 and Schmookler, 1966). Most studies typically find a strong positive relationship between patenting and R\&D activity. Pakes and Griliches (1980), for example, found a statistically significant relationship between the R\&D expenditures of a firm and the number of patents received at the cross-sectional level, across firms and industries. This result was also confirmed by Hall, Griliches and Hausman (1984) by using a newly developed fixed effects estimator for count data such as patent counts. Hall, Griliches and Hausman (1984) report an elasticity between 0.3 and 0.6 in a panel of U.S. firms (see also Bound et al., 1984, for further evidence). Other studies with a similar research topic and extensions, such as the impact of spillovers, are Cincera (1997), Crépon and Duguet (1997a, b) Licht and Zoz (1998), Meliciani (2000) and Hall and Ziedonis (2001). Blundell et al. (1999) use the pre-sample information of the dependent count variable in order to develop a different panel estimator (see below). ${ }^{17}$

One might argue that firms tend to patent the less important inventions in order to secure the details of the newly developed products or processes. If this were true, patents would have no impact on profitability. However several studies find a strong effect of patents on profitability. Recent evidence on the impact of patents on market value is presented by Hall, Jaffe and Trajtenberg (2005) as well as by Hall, Thoma and Torrisi (2007). Czarnitzki and Kraft (2007) estimate a positive impact of the patent stock on profitability.

To summarize, patents have their shortcomings as indicators of innovative success; however, this is of course also true for other measures of innovative activity, as no perfect variable exists. Furthermore, most empirical studies found a strong relation between R\&D and patents. We therefore regard the number of patents as a good proxy for innovation. One may also argue that the use of an outcome variable of the innovation production process (such as 
patents) is superior to an input variable (such as $R \& D$ ) where the impact of co-determination is analysed. This is because codetermined firms are likely to do a lot of research, which may not necessarily be efficient. Our number of patents includes both national and European patents, which were introduced in 1978.

We compare the years before the introduction of the co-determination law 1971-1976 with the periods 1981-1990 after the law became effective. In both time periods the large and after 1976 co-determined firms are compared with smaller ones. As co-determination is inevitably connected with firm size we want to identify the impact of it by comparing the relative performance of co-determined firms in relation to other firms.

Aside of co-determination a number of control variables are used. Clearly firm size has to be taken into account. We use the number of employees and the number of employees squared. A description of the variables and relevant statistical data are shown in tables one and two.

Table 2 shows the mean values and the standard deviations for our sample. It becomes obvious that patents have a high standard deviation. This is an indicator that we have a high dispersion and this has consequences for the research methodology to be discussed below. Clearly there are industries with very low innovation and others like for example chemistry or automobiles which have a very high number of patents. ${ }^{18}$ As one can see from figures 1 - 3 in the appendix, not surprisingly, patents also strongly vary over industries as well as over time and federal states. The average number of employees in our sample is 8312, which implies co-determination for a large number of firms. Our largest firm has 280.000 employees, while we also have small firms with less than 500 workers.

\footnotetext{
17 Recent studies analyzing the relationship between R\&R expenditures and patenting include Baudry and Dumont (2006) and Kim and Marschke (2004).

${ }^{18}$ The strongly differing values of the capital intensities also underline this fact.
} 


\begin{tabular}{|c|c|}
\hline Firm Level Data & Definition \\
\hline KapInt & $\begin{array}{l}\text { Capital intensity (Capital fixed and working per } \\
\text { employee) }\end{array}$ \\
\hline Emp & Number of employees \\
\hline Emp2 & Square of the number of employees \\
\hline COD80 & Co-determination dummy \\
\hline & $\begin{array}{l}\text { Dummy = } 1 \text { if employment } \geq 2000 \text { and year }>1976 \\
\text { (Firm is actually co-determined) }\end{array}$ \\
\hline COD & Dummy $=1$ if employment $\geq 2000$ \\
\hline InvAge & Inverse of Firm Age \\
\hline Export & $\begin{array}{l}\text { Export ratio - Value of Exports divided by total Sales } \\
\text { on the Firm Level }\end{array}$ \\
\hline Fixedeff & $\begin{array}{l}\text { Average patent distributions of the pre sample period } \\
(1968-1971)\end{array}$ \\
\hline Fixeddu & Dummy $=1$ if Fixedeff $>0$ \\
\hline Industry Level Data & Definition \\
\hline Conc6 & Concentration Ratio on the Four-Digit Industry Level \\
\hline Import & Import ratio - Value of Imports divided by Sales \\
\hline & Volume on the two digit industry level (SYPRO 2) \\
\hline Industry dummies & $\begin{array}{l}\text { Industry dummies based on four digit industries } \\
\text { (SYPRO 4) }\end{array}$ \\
\hline Time Dummies & Dummy variables for all but one year \\
\hline Regional Dummies & Dummy variables for the federal states (Bundesländer) \\
\hline
\end{tabular}

Table 2: Descriptive Statistics:

\begin{tabular}{|l|c|c|c|c|c|c|c|}
\hline & Patents & Export & Import & Emp & KapInt & Conc6 & Age \\
\hline Min & 0 & 0 & 0.005 & 53 & 15.30 & 6.5 & 1 \\
\hline Max & 399 & 0.87 & 1.00 & 282000 & 5136.43 & 71.2 & 540 \\
\hline Mean & 10.86 & 0.33 & 0.25 & 0.24 & 112.60 & 27.51 & 106.14 \\
\hline SD & 31.13 & 0.21 & 0.18 & 23776.59 & 166.59 & 18.35 & 63.23 \\
\hline
\end{tabular}

Note: Patens, Emp and Age are given in absolute values, Export and Import are given in quotas (relative to revenues), KapInt is defined as (capital assets + current assets [both in 1000 Euros])/Emp and Conc6 is expressed as a percentage.

We have a specific size problem. Co-determination is connected to firm size and although we use size and size squared, there might be a size advantage or disadvantage, which is relevant for firms with about 2000 employees. Such an effect can be differentiated from the codetermination impact if - as we do - a before and after comparison is undertaken. The dummyvariable COD80 has unit value in the case of firms, which are co-determined in the eighties. In addition the variable COD assumes unit values for the same firms but not only for the observations from the eighties but also for the observation from the seventies, before codetermination became effective. This variable is expected to catch possible size effects. Thus 
the coefficient of COD80 is expected to estimate the "pure" impact of co-determination aside of any size (dis-)advantage.

The co-determination law had to be implemented until 1978. We use data from 1981 onwards as the time period of restructuring might take longer and as patents measure the innovativeness only with some lag, since they are the outcome of an R\&D process. Codetermination will (if at all) at first influence the research process and this in turn will affect the innovative output after some time. Because of this possible delay we use data until 1990.

We use information about 148 firms from the manufacturing sector. 61 of them are codetermined after 1976 and 87 are not. There are some missing observations in the panel and therefore we can use only 2062 observations overall. The following model with the dependent variable $\mathrm{P}$ (patents) is used ${ }^{19}$ :

$$
\begin{aligned}
\mathrm{P}= & \beta_{0}+\beta_{1} \cdot \text { Emp }+\beta_{2} \cdot \text { Emp }^{2}+\beta_{3} \cdot \text { Conc6 }+\beta_{4} \cdot \text { KapInt }+\beta_{5} \cdot \text { Import }+\beta_{6} \cdot \text { Export } \\
& +\beta_{7} \cdot \text { COD }+\beta_{8} \cdot \text { COD80 }+\beta_{9} \cdot \text { InvAge }+ \text { Industry Dummies }+ \text { Time Dummies }+
\end{aligned}
$$

Regional Dummies

As mentioned above, COD has unit value for the years 1971-1990, while COD80 has unit value only in the years 1981-1990. The coefficient of COD is expected to show possible size effects, which are relevant at an employment level of 2000 or more and COD80 should estimate the real effects of the law in question. Hence in the eighties, for the co-determined firms, the sum of the coefficients $\beta_{7}$ and $\beta_{8}$ is relevant. This is a difference in differences estimator (Wooldridge 2002, 130).

As exposed in section 2, before 1976 the firms with more than 500 employees had a one third co-determination right. Hence after 1976 for these firms it is a move from a one-third codetermination to quasi-parity co-determination. An additional problem is it, that after 1976 the "medium-sized” firms with 500 employees or more, but less than 2000 have still the one third co-determination, and might differ from the small ones without any codetermination. Although one third co-determination is much less controversially discussed, there might still be an effect. In order to test for such a possibility, we estimated count data models with three groups of firms. The results are presented in an appendix.

The other variables are standard in studies on innovative activity. Employment and employment squared are used to check for size effects. In many studies it is estimated that innovative activity rises with size, but at a decreasing rate and above a certain size level the

\footnotetext{
${ }^{19}$ The count data model necessary for estimating such an equation is explained below.
} 
innovativeness is reduced ${ }^{20}$ (Kamien, Schwarz, 1982). Acs and Audretsch (1988) show that the innovative output of small and medium-sized firms in comparison to the large ones may depend on the particular industry.

Concentration ratios are also found in many investigations. It is a long discussion that concerns the impact of market concentration, with controversial opinions and also very controversial results. We do not intend to participate in this discussion but just use CONC6 as a control variable. Our concentration variable is the market share of the six largest producers, measured on the four digit level. The variable is computed by the German monopoly commission by use of data from the German statistical office. Involvement in international trade is related to this variable. Export and import ratios are use to take account of the firm's engagement in international competition.

Mansfield, Romeo and Wagner (1979) examine large-scale American enterprises and show that with a rise of exports the innovation efforts also raise. Hirschey and Caves (1981) also conclude that international expansion and innovation activity are positively related. Bertschek (1995) explicitly examines what kind of influence is exerted by import ratios. Using a large sample of 1270 German enterprises from the manufacturing industry, she finds that imports have a positive effect on innovativeness. The variable firm age is included, as many firms are established to market an innovation and over time the innovativeness will perhaps be reduced. Hansen (1992) finds support for this hypothesis. As a share of our firms is very old, we do not use the absolute value but, as a simple method to take account of nonlinearities, the inverse of firm age is included.

Capital intensity is used, as this variable may express the technological opportunity of the firm. With high capital intensity, it is probable that technology plays a major role. If capital is sunk to a degree, this variable may also stand for barriers to entry ${ }^{21}$. Earlier studies show that capital intensity has a positive impact on innovativeness [cf. Crepon, Duguet and Mairesse (1998) or Zimmermann and Schwalbach (1991)]. Finally, industry dummies are included, as clearly the potential for innovation is very different depending on the industry and one must take this into account.

\subsection{Econometric Methodology}

Patent data are a classic example for count data. In this case the dependent variable assumes different discrete values including the value zero. The analysis is usually based on count data

\footnotetext{
${ }^{20}$ This question has its roots in suggestions by Schumpeter (1942) and later Galbraith (1952).
} 
models. A popular approach is the Poisson model, which applies the Poisson distribution for the data generating process. This model is relatively easy to implement. The disadvantage is the assumption that the conditional expected value is equal to the variance. In many cases this assumption is violated, as over-dispersion occurs.

Much less frequently the opposite case of under-dispersion arises, i.e. the situation that the conditional variance is smaller than the conditional expectancy value. In the case of overdispersion there is a danger of an underestimation of the true variances of the parameter estimations. The Poisson model can be enlarged by help of a stochastic component and if a gamma-distribution is assumed, the Negative Binomial model is calculated. This model includes the Poisson distribution for specific parameter values. It can be determined whether the Poisson model or the more general negative binomial model should be applied by means of the Cameron and Trivendi (1990) test. It is based on testing the assumption of a mean value which is equal to the variance and is therefore easy to implement. In our case, the Cameron and Trivedi (1990) test clearly points to the relevance of the negative binomial model.

Count data models are based on the assumption that the exogenous variables describe the move from 0 to 1 in much the same way as, for example, from 186 to 187. However many firms do no research at all and therefore they will never have a patent. Hence, in many cases there is a fundamental difference between observations with the value zero and those which have one or more patents.

For this reason, the so-called zero-inflated models have been developed. These are enlargements of the basic Poisson or Negative Binomial models. In the first step, it is analyzed whether the dependent variable is zero or larger than zero. Any observation larger than zero is adjusted to one, and then either a Logit or a Probit model is applied. In the second step, the Poisson or Negative Binomial model is applied for those observations, where the dependent variable is one or larger.

In contrast to the original zero-inflated poisson (ZIP) model we follow Mullahey (1986) and make a further generalization. Because of the tendency of over-dispersion we do not use the Poisson model, but the more general negative binominal distribution, which permits over dispersion. The Vuong statistic tests for the appropriability of the zero-inflated models instead of standard count data models.

\footnotetext{
${ }^{21}$ Cf. for the theory of sunk costs and barriers to entry Baumol, Panzar und Willig (1982).
} 
Table 3: Results of the NegBin and ZINB Models

\begin{tabular}{|c|c|c|c|c|}
\hline & \multicolumn{2}{|c|}{ NegBin } & \multicolumn{2}{|c|}{ ZINB } \\
\hline & Model I & Model II & Model III & Model IV \\
\hline Cod & $\begin{array}{c}1.00 \\
(5.84)\end{array}$ & $\begin{array}{c}1.26 \\
(8.03)\end{array}$ & $\begin{array}{c}0.66 \\
(2.26)\end{array}$ & $\begin{array}{c}1.73 \\
(9.31)\end{array}$ \\
\hline Cod80 & $\begin{array}{c}0.33 \\
(2.89)\end{array}$ & $\begin{array}{c}0.27 \\
(1.75)\end{array}$ & $\begin{array}{c}0.51 \\
(4.38)\end{array}$ & $\begin{array}{l}-0.05 \\
(-0.24)\end{array}$ \\
\hline Export & $\begin{array}{r}2.02 \\
(4.41)\end{array}$ & $\begin{array}{c}1.96 \\
(3.38)\end{array}$ & $\begin{array}{c}1.03 \\
(2.57)\end{array}$ & $\begin{array}{l}2.03 \\
(6.23)\end{array}$ \\
\hline Import & $\begin{array}{l}-3.81 \\
(1.36)\end{array}$ & $\begin{array}{l}-1.04 \\
(-1.03)\end{array}$ & $\begin{array}{l}-2.24 \\
(-1.57)\end{array}$ & $\begin{array}{c}0.37 \\
(0.54)\end{array}$ \\
\hline Emp & $\begin{array}{c}0.00005 \\
(5.34)\end{array}$ & - & $\begin{array}{c}0.00005 \\
(5.67)\end{array}$ & - \\
\hline Emp2 & $\begin{array}{c}-2.08 \mathrm{e}-10 \\
(-4.98)\end{array}$ & - & $\begin{array}{c}-1.91 \mathrm{e}-10 \\
(-5.30)\end{array}$ & - \\
\hline KapInt & $\begin{array}{l}0.0009 \\
(1.78)\end{array}$ & $\begin{array}{l}0.002 \\
(3.98)\end{array}$ & $\begin{array}{c}0.0003 \\
(3.39)\end{array}$ & $\begin{array}{l}0.001 \\
(0.93)\end{array}$ \\
\hline Conc6 & $\begin{array}{l}-.008 \\
(-0.32)\end{array}$ & $\begin{array}{r}0.02 \\
(3.71)\end{array}$ & $\begin{array}{l}-0.02 \\
(-1.08)\end{array}$ & $\begin{array}{c}0.02 \\
(5.22)\end{array}$ \\
\hline InvAge & $\begin{array}{l}-1.03 \\
(-0.96)\end{array}$ & $\begin{array}{l}-1.40 \\
(-1.53)\end{array}$ & $\begin{array}{c}0.07 \\
(0.07)\end{array}$ & $\begin{array}{c}-2.74 \\
(-2.83)\end{array}$ \\
\hline Constant & $\begin{array}{c}0.95 \\
(2.71)\end{array}$ & $\begin{array}{l}-0.50 \\
(-4.04)\end{array}$ & $\begin{array}{c}1.84 \\
(3.60)\end{array}$ & $\begin{array}{l}-0.49 \\
(-1.80)\end{array}$ \\
\hline Industry Dummies & Yes & No & Yes & No \\
\hline Regional Dummies & Yes & No & Yes & No \\
\hline Time Dummies & Yes & No & Yes & No \\
\hline Log-likelihood & -4612.47 & -4861.09 & -4501.24 & -4841.14 \\
\hline $\begin{array}{l}\text { Vuong-Statistik }{ }^{22} \\
(\operatorname{Pr}>\mathrm{z})\end{array}$ & - & - & $\begin{array}{c}6.59 \\
(0.00)\end{array}$ & $\begin{array}{r}7.28 \\
(0.00)\end{array}$ \\
\hline $\begin{array}{l}\text { Alpha [Over-dispersion] } \\
\text { (Prob>chi) }\end{array}$ & $\begin{array}{c}1.53 \\
(0.00)\end{array}$ & $\begin{array}{r}2.20 \\
(0.00)\end{array}$ & $\begin{array}{c}0.93 \\
(0.00)\end{array}$ & $\begin{array}{c}1.69 \\
(0.00)\end{array}$ \\
\hline Nobs & & & & \\
\hline Pseudo- $\mathbf{R}^{2}$ & 0.16 & 0.11 & - & - \\
\hline
\end{tabular}

Notes: Moulton corrected as well as heteroscedasticity-consistent t-values in parentheses.

22 The test developed by Vuong (1989) was applied for the first time by Greene (1994) to the question of whether ZIP or ZINB approaches have to be preferred in relation to the classical Poisson or negative Binomial models. In our case the high values of 5.83 and 8.18 shows a dominance of the ZINB model. 
A largely ignored, but despite of this a very relevant issue is the possible bias, that arises if individual data is connected with aggregated information, like for example the combination of firm data with industry variables. Moulton $(1986,1990)$ has demonstrated how large this bias from clustering can be and has proposed a method to correct the standard errors. We take account of this by presenting in the tables both the standard (heteroscedasticity-consistent) and the clustering-corrected (and heteroscedasticity-consistent) t-values.

In the first step of the empirical part of the analysis, the NegBin and the ZINB estimators are estimated using pooled data. As one can recognize from Table 3, the results depend on the econometric model. The negative binomial model leads to an significant coefficient of COD80. However, with the zero-inflated model this variable becomes insignificant at usual levels when dropping the dummies. The Vuong statistic points to the superiority of the ZINB model, so that we conclude at this stage of the analysis that co-determination has at least not reduced the innovative activity of German firms.

\subsection{Econometric Panel Models}

Every panel study must take account of the relevance of fixed effects, although this is not a trivial task in the case of count data. As it is well known, firms may have permanent differences with respect to innovative activity. Some are active research companies, while others have no particular ambition to be the innovative leaders. Therefore, firm-specific effects are quite likely in the given context and they must be analysed somehow.

Fixed effects models for count data models like that developed by Hausman, Hall and Griliches (1984) cannot be applied in our case, as the co-determination status does not change for any firm. This implies that the individual effect cannot be differentiated from the effect of the co-determination variable.

A solution to this problem is the approach developed by Blundell, Griffith and van Reenen (1999). In their model, the values from a pre-sample period on patents are used to identify the individual effect. This is a very useful suggestion in our case, as information from a pre-sample period is available. Blundell, Griffith and van Reenen (1999) propose a new method for considering firm-specific effects. They argue that the fixed effect is expressed as the stock of past innovations. Hence, if the stock of past innovation is used in the estimations, the individual effects are analyzed. They suggest using the pre-sample mean of innovations for every firm. They compare this estimation procedure with alternative methods proposed by Chamberlain (1992) and Wooldridge (1997) which are based on quasi-differenced methods of 
moments. Using Monte-Carlo simulations, they conclude that their method produces lower mean square errors than quasi-differencing.

Using for simplicity the standard Poisson model for count data ${ }^{23}$, the conditional mean of the number of patents $(P)$ can be written as:

$$
P_{i t}=\exp \left[x_{i t}^{\prime} \beta+\eta_{i}\right]
$$

where $x_{i t}$ is the vector of observable explanatory variables and $\beta$ stands for the coefficient vector. The term $\eta_{i}$ represents an unobservable individual firm specific effect, which reflects permanent differences in innovative activity. Adding an error term $v_{i t}$, which is assumed to have zero mean and finite variance leads to $P_{i t}=\exp \left[x_{i t}^{\prime} \beta+\eta_{i}\right]+v_{i t}$.

If the pre-sample size is assumed to be $0,-1,-2, \ldots .,-\theta$, averages of the variables in equation (14) (including the stochastic component) over the pre-sample period are:

$$
\frac{\sum_{t=0}^{-\theta} P_{i t}}{-\theta}=\frac{\sum_{t=0}^{-\theta} \exp \left(x_{i t}^{\prime} \beta+\eta_{i}\right)}{-\theta}+\frac{\sum_{t=0}^{-\theta} v_{i t}}{-\theta} .
$$

The probability is (taking logs):

$$
\ln \left[p \lim \frac{\sum_{t=0}^{-\theta} P_{i t}}{-\theta}\right]=\ln \left[p \lim \frac{\sum_{t=0}^{-\theta} \exp \left(x_{i t}^{\prime} \beta\right)}{-\theta}\right]+\eta_{i}
$$

Blundell, Griffith and van Reenen (1999) show that for a multivariate normal distribution of $x_{i t}$ for each i with mean $\phi \eta_{i}$ and variance covariance matrix $\Omega_{x}$ one can write:

$$
\ln \left[p \lim \frac{\sum_{t=0}^{-\theta} P_{i t}}{-\theta}\right]=\beta^{\prime} \phi \eta_{i}+\beta^{\prime} \Omega_{x} \beta / 2+\eta_{i}
$$


And this can be simplified to $\eta_{i}=\vartheta+\ln \left[p \lim \frac{\sum_{t=0}^{-\theta} P_{i t}}{-\theta}\right]$. Defining for simplicity $\ln \bar{P}_{i 0}=\ln \left[p \lim \frac{\sum_{t=0}^{-\theta} P_{i t}}{-\theta}\right]$ and inserting this relation into (14) we have

$$
E\left\langle P_{i t} \mid x_{i t}, \eta_{i}\right\rangle=\exp \left(x_{i t}^{\prime} \beta+\vartheta+\zeta \ln \bar{P}_{i 0}\right)
$$

where $\vartheta$ adjusts the constant term in $\beta$. Clearly the question arises as to what the pre-sample period is. Blundell et al use the first period number of innovations as the relevant figure and add a dummy variable, which has unit value if a firm has any innovation during the period in question. We use the number of patents in the periods 1968-1971 as the relevant pre-sample information and include the mentioned dummy variable as well ${ }^{24}$. The results are shown in Table 4.

Using fixed effects instead of pooled regressions yields a positive impact of codetermination on firms' innovative behavior. All negative binomial models as well as zeroinflated regressions show positive and statistically significant coefficients of Cod80. Moreover, results are also robust against variations in specifications. Dropping dummies as well as firm size variables does not lead to serious variations.

Moreover, we find a non-linear, i.e. a bell-shaped, relation between firms size and innovation. Given the respective parameters for EMP and EMP2 a threshold value can be calculated which suggest an optimal employment of about 130000 employees. Furthermore, while exports and capital intensity seem to have a positive influence on innovation imports and the inverse of firms' age have (if any) a negative one. The impact of concentration is, however, ambiguous.

\footnotetext{
${ }^{23}$ For our estimations we use the NegBin model as the Poisson model is rejected. Hence in our case instead of (14) we have $P_{i t}=\exp \left[x_{i t}^{\prime} \beta+\eta_{i}+\varepsilon_{i}\right]$, where $\varepsilon_{\mathrm{i}}$ stands for an error term.

${ }^{24}$ This dummy variable is necessary, as many firms have no patents and in order to calculate a logarithmic value, an arbitrary small number has to be used. The dummy variable takes account of the firms with no patents and the method to deal with the zeros.
} 
Table 4: Results of the NegBin and ZINB Models

\begin{tabular}{|c|c|c|c|c|}
\hline & & & & \\
\hline & Model I & Model II & Model III & Model IV \\
\hline Fivedeff & 0.006 & 0.01 & 0.008 & 0.01 \\
\hline Fixedeti & (1.72) & $(2.77)$ & (3.93) & (3.54) \\
\hline Fixeddu & 1.37 & & & 1.01 \\
\hline FIxedau & (5.05) & (4.96) & (1.60) & (3.93) \\
\hline Cod & 0.63 & 0.72 & 0.64 & 0.62 \\
\hline Cod & (4.54) & $(2.93)$ & $(2.58)$ & $(2.01)$ \\
\hline Cod80 & 0.45 & 0.46 & 0.48 & 0.49 \\
\hline Cod80 & (3.59) & (4.28) & (2.94) & (3.54) \\
\hline Fxpert & 1.51 & 2.06 & 0.69 & 1.37 \\
\hline & (3.68) & $(3.44)$ & $(1.76)$ & $(2.62)$ \\
\hline Import & -2.40 & -0.71 & -0.95 & 0.46 \\
\hline & $(-2.44)$ & $(-0.95)$ & $(-1.08)$ & $(0.60)$ \\
\hline Fmn & 0.00003 & & 0.00003 & \\
\hline Emp & (3.60) & - & (4.07) & - \\
\hline Emn2 & $-1.42 \mathrm{e}-10$ & _- & $-1.23 e-10$ & 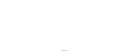 \\
\hline & $(-3.82)$ & & $(-3.76)$ & \\
\hline KanInt & 0.0005 & 0.0006 & 0.0002 & 0.003 \\
\hline & (2.04) & (1.25) & (1.92) & $(2.50)$ \\
\hline Conct & 0.002 & 0.01 & -0.02 & 0.01 \\
\hline Conce & (0.09) & (3.21) & $(-1.10)$ & (2.80) \\
\hline InvAgo & -1.49 & -0.75 & -0.34 & -0.29 \\
\hline minAge & $(-2.08)$ & $(-0.48)$ & $(-0.65)$ & $(-0.14)$ \\
\hline Constant & -0.23 & -1.22 & 1.32 & -0.63 \\
\hline Constant & $(-0.54)$ & $(-4.75)$ & (3.11) & $(-1.95)$ \\
\hline Industry Dummies & Yes & No & Yes & No \\
\hline Regional Dummies & Yes & No & Yes & No \\
\hline Time Dummies & Yes & No & Yes & No \\
\hline Log-likelihood & -4471.43 & -4716.62 & -4343.28 & -4460.85 \\
\hline Vuong-Statistic & 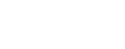 & 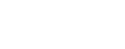 & 7.08 & 5.06 \\
\hline$(\operatorname{Pr}>z)$ & & & $(0.00)$ & $(0.00)$ \\
\hline Alpha [Over-dispersion] & 1.18 & 1.77 & 0.69 & 1.17 \\
\hline (Prob>chi) & $(0.00)$ & $(0.00)$ & $(0.00)$ & $(0.00)$ \\
\hline Nobs & & & & \\
\hline Non-Zero obs & & & & \\
\hline LR-Chi' ${ }^{2}$ 0: all Coeff. eqal zero & 2037.11 & 1546.73 & 1491.60 & 1147.03 \\
\hline (Pr $>$ chi) & $(0.00)$ & $(0.00)$ & $(0.00)$ & $(0.00)$ \\
\hline Pseudo-R $\mathbf{R}^{2}$ & 0.19 & 0.14 & - & - \\
\hline Threshold Value of Firm Size & 123591 & - & 135772 & - \\
\hline
\end{tabular}

Notes: Moulton corrected as well as heteroscedasticity-consistent $t$-values in parentheses. 
The reader might ask how large the effect of co-determination is, and this is a simple method to check for the plausibility of the results. In order to quantify the influence of codetermination, the marginal effects have to be calculated. They are defined as:

$$
\frac{\partial E[y \mid x]}{\partial x}=\lambda_{i} \beta
$$

where $\lambda_{i}$ is the expected value of the dependent variable. All marginal effects are calculated at the mean values of all explanatory variables. It may be questioned, whether marginal effects are meaningful for dummy variables. As an alternative, one may calculate the marginal effect of a dummy variable called $d$ by the difference of two estimates: $E\left[y \mid \bar{x}_{0}, d=1\right]-E\left[y \mid \bar{x}_{0}, d=0\right]$, where $x_{0}$ denotes the means of all others variables. The difference is the marginal effect and one realizes that it is practically similar as if the derivative of $d$ is taken as if it were a continuous variable and using $\lambda_{i} \beta$. The marginal effects are presented in table 5.

Table 5: Marginal Effects

\begin{tabular}{|l|c|c|}
\hline \multirow{2}{*}{} & \multicolumn{2}{|c|}{ Marginal Effects } \\
\cline { 2 - 4 } & $\begin{array}{c}\text { Negative Binomial Regression } \\
\text { Model I }\end{array}$ & ZINB-Regression \\
\hline Cod & 1.04 & 1.30 \\
\hline Cod80 & 0.76 & 1.24 \\
\hline Export & 2.30 & 2.91 \\
\hline Import & -3.66 & -2.69 \\
\hline Emp & 0.00005 & 0.00006 \\
\hline Emp2 & $-2.16 \mathrm{e}-10$ & $-2.72 \mathrm{e}-10$ \\
\hline KapInt & 0.0007 & 0.0008 \\
\hline Conc6 & 0.003 & -0.03 \\
\hline InvAge & -2.26 & -2.52 \\
\hline Fixedeff & 0.01 & 0.01 \\
\hline
\end{tabular}

The marginal effect of the most important variable Cod80 is 0.76 (NegBin) and 1.24 (ZINB). These estimates have to be compared with the mean values of the number of patents. In the 
case of NegBin the mean value is 10.86 and for the ZINB the respective value is 20.07 as here only the firms with one or more patents are used during the second step of the estimation and the marginal effect refers to this part of ZINB. The marginal effects are $6.99 \%$ respectively $6.17 \%$ of the mean values and therefore the marginal effect is of moderate magnitude and seems to be realistic.

In our view this is important empirical evidence against the popular opinion that codetermination impedes innovation. If innovation really leads to delayed decision making there must be offsetting counter effects. These be could information advantages, control of the behaviour of opportunistic managers or effects described by our theoretical model. The codetermined firm has a stronger incentive towards growth than a comparable company without such a bargaining system. Growth is among other factors determined by innovative activity and our empirical evidence is in accordance with this explanation.

Summing up, we find strong evidence for a positive impact of co-determination on innovation. The results are relatively robust against different specifications and also the marginal effects seem to be reasonable.

\section{Conclusion}

This paper discusses and estimates the effects of co-determination on innovative activity. The theory leads to ambiguous hypotheses concerning the impact of co-determination. We present a simple model applying Nash-bargaining on employment determination and R\&D. Codetermined firms are compared with standard profit-maximizing companies and it turns out that in our model the co-determined firm will carry out more R\&D.

In the second part, we present the results of an empirical study. The sample consists of 148 firms over the periods 1971-1976 and 1981-1990. Innovation is measured by the number of patents. We use the negative Binomial and the Zero-Inflated Negative Binomial models for estimation and combine these models with the Blundell, Griffith and van Reenen (1999) approach to include fixed effects.

Our results point to the conclusion that co-determination has no negative impact on innovativeness. If at all, rather a positive effect can be estimated. Hence we cannot support the frequently heard presumption that co-determination will reduce flexibility and by this the innovative potential of companies. The marginal effects show that co-determination has no large impact. The additional consideration of one third co-determination has no effect on the main results. There are several possible explanations for this result. Co-determination may affect worker motivation and enhance information exchange. Information is an important 
input regarding the success of innovation projects. Moreover management might be prevented from opportunistic behavior, which would be neither in the interest of capital owners nor in that of the employees. Finally our theoretical model points to the impact of bargaining for growth incentives. Innovation clearly affects growth possibilities and therefore the higher innovative activity might be a result of modified incentives.

This study presents empirical results concerning very controversially discussed hypotheses. Apparently, worker’s representatives do not generally oppose technical progress. Most likely they regard long-term investment into knowledge capital as an opportunity to secure jobs. Hence the property rights' view that employees are more shortsightened in their actions than capital owners is not supported by the results of this study.However, there is still a lot to be done. Perhaps other studies can check the robustness of our results by using other measures for innovativeness like e.g. R\&D expenditures. 


\section{Appendix: Estimations with one-third Codetermination}

The effect of one third co-determination is estimated in two different ways: On the one hand a variable $1 / 3$ Codetermination is specified, which has unit value, if a firm has actually this kind of worker participation. This means before 1977 a firm with 500 employees or more has 1/3 Co-determination and after 1976 an observation is in this category, if it has between 500 and 1999 employees. On the other hand the variable COD500-2000 has unit value, if a firm has 500 or more but below 2000 employees irrespective of the time period. Both variables are highly correlated and cannot be used simultaneously. The reader will perhaps prefer the variable 1/3 Codetermination, but this variable does not control for size effects and it is not a difference in differences estimator, as the firms are not the same before and after 1976.

The results are presented in table 6. It turns out, that the additional consideration of one third co-determination has no impact on our main results: Both variables standing for one third co-determination are significant. Also quasi-parity co-determination is still positively significant. 
Table 6: Results of the ZINB Models with one third Co-determination

\begin{tabular}{|c|c|c|}
\hline & ZiNB & ZiNB \\
\hline 1/3 Codetermination & $\begin{array}{c}0.53 \\
(5.07\end{array}$ & - \\
\hline COD500-2000 & - & $\begin{array}{c}0.64 \\
(4.89)\end{array}$ \\
\hline Fixedeff & $\begin{array}{l}0.008 \\
(6.28)\end{array}$ & $\begin{array}{l}0.008 \\
(6.05)\end{array}$ \\
\hline Fixeddu & $\begin{array}{c}0.98 \\
(11.38)\end{array}$ & $\begin{array}{c}0.96 \\
(10.09)\end{array}$ \\
\hline Cod & $\begin{array}{c}0.86 \\
(6.17)\end{array}$ & $\begin{array}{c}0.98 \\
(11.10)\end{array}$ \\
\hline Cod80 & $\begin{array}{l}0.09 \\
(0.75)\end{array}$ & $\begin{array}{l}0.58 \\
(5.98)\end{array}$ \\
\hline Export & $\begin{array}{c}0.87 \\
(4.28)\end{array}$ & $\begin{array}{c}0.89 \\
(2.05)\end{array}$ \\
\hline Import & $\begin{array}{c}0.73 \\
(2.64)\end{array}$ & $\begin{array}{c}0.74 \\
(2.96)\end{array}$ \\
\hline Emp & $\begin{array}{c}0.00003 \\
(4.82)\end{array}$ & $\begin{array}{c}0.00003 \\
(8.33)\end{array}$ \\
\hline Emp2 & $\begin{array}{c}-1.31 \mathrm{e}-10 \\
(-8.44)\end{array}$ & $\begin{array}{c}-1.31 \mathrm{e}-10 \\
(-8.46)\end{array}$ \\
\hline KapInt & $\begin{array}{c}0.0003 \\
(1.88)\end{array}$ & $\begin{array}{c}0.0004 \\
(2.08)\end{array}$ \\
\hline Conc6 & $\begin{array}{l}0.003 \\
(1.27)\end{array}$ & $\begin{array}{l}0.002 \\
(1.16)\end{array}$ \\
\hline InvAge & $\begin{array}{c}0.21 \\
(0.23)\end{array}$ & $\begin{array}{c}0.10 \\
(0.12)\end{array}$ \\
\hline Constant & $\begin{array}{c}-0.70 \\
(4.55)\end{array}$ & $\begin{array}{c}-0.79 \\
(-4.90)\end{array}$ \\
\hline Vuong-value & $\begin{array}{c}5.54 \\
(0.00)\end{array}$ & $\begin{array}{c}5.38 \\
(0.00)\end{array}$ \\
\hline Alpha & $\begin{array}{c}1.08 \\
(0.00)\end{array}$ & $\begin{array}{c}1.08 \\
(0.00)\end{array}$ \\
\hline LR-Chi' ${ }^{2}$ & $\begin{array}{c}1227.41 \\
(0.00)\end{array}$ & $\begin{array}{c}1226.74 \\
(0.00)\end{array}$ \\
\hline Log-likelihood & -4582.99 & -4583.33 \\
\hline
\end{tabular}

Notes: Moulton corrected as well as heteroscedasticity-consistent t-values in parentheses 


\section{Appendix: Figures}

Figure 1: Patens by Industry

\section{Patents by Industry (Sypro2 level)}

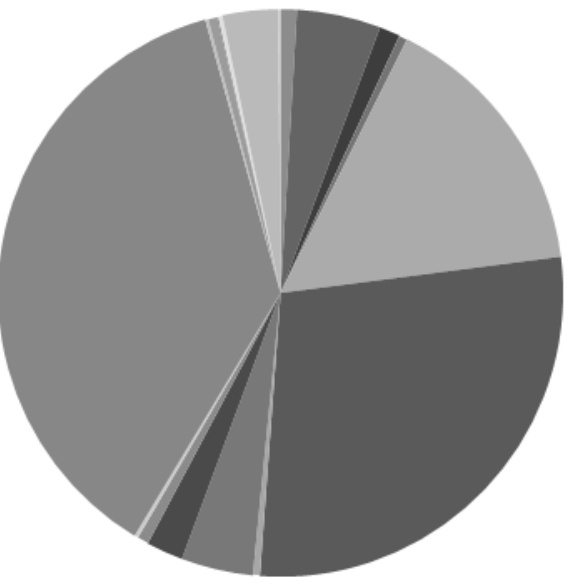

Figure 2: Patents by Federal State

\section{Patents by Federal State}

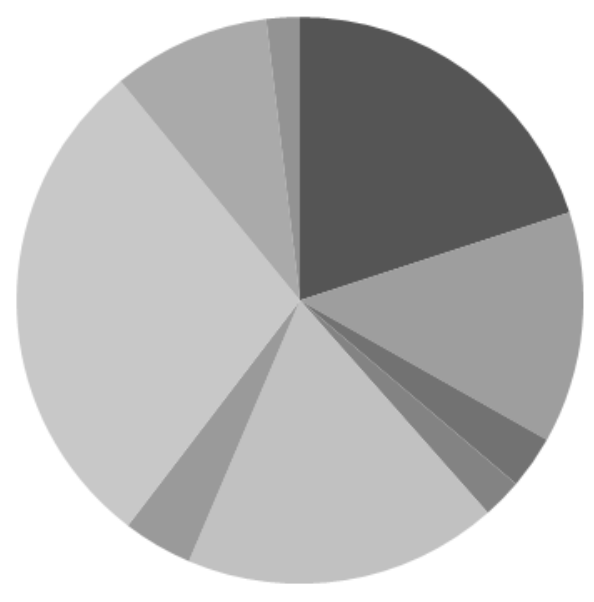

- Baden-Württemberg

- Bavaria

Berlin

- Bremen

Hamburg

Hesse

- Lower Saxony

North Rhein-Westphalia

Rhineland-Palatinate 
Figure 3: Patents by Industry and Year

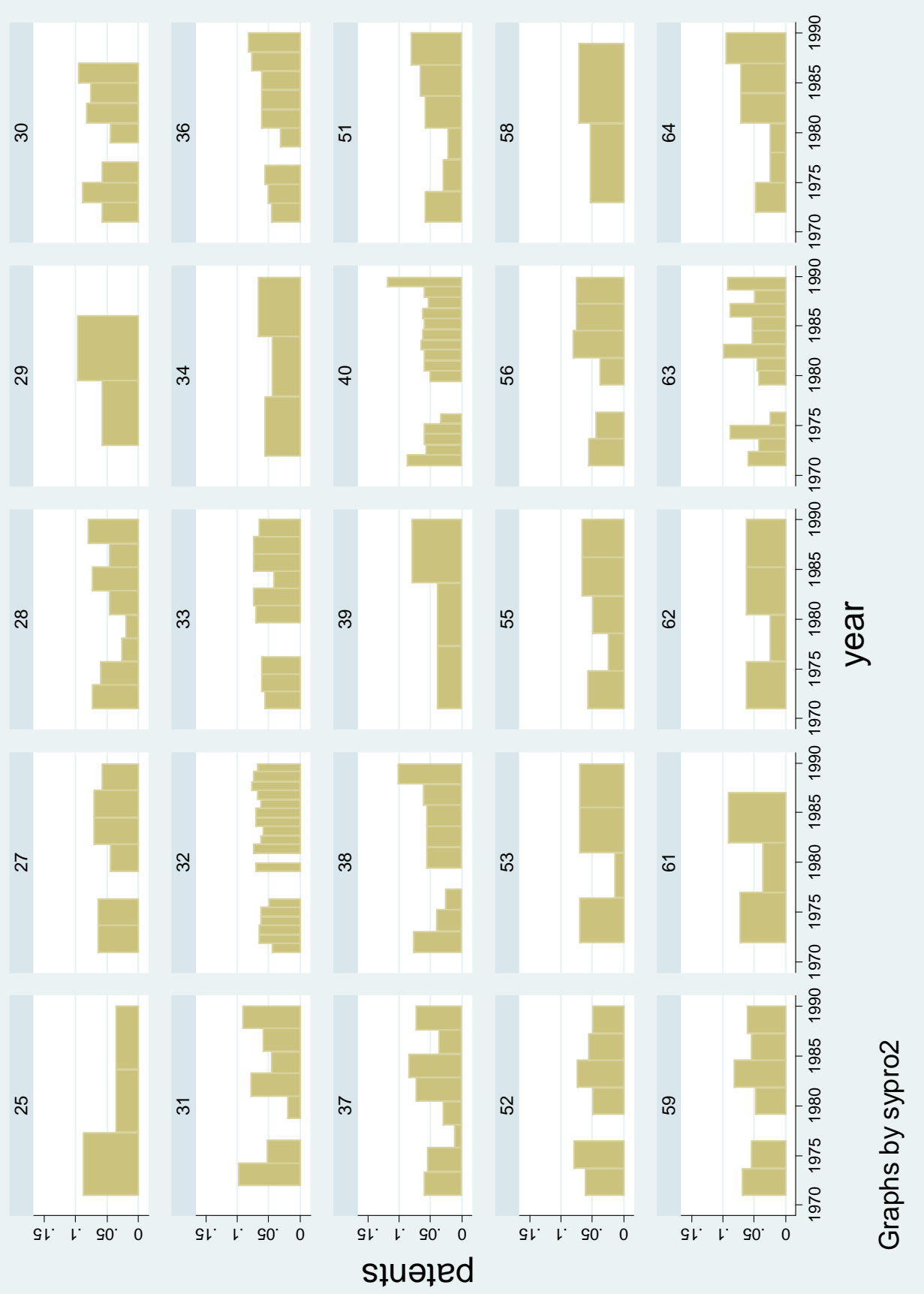




\section{References}

Acs, Z.J. and Audretsch, D.B. (1988), Innovation in Large and Small Firms, American Economic Review, vol. 78, 678-690.

Acs, Z. J. and Audretsch, D. B. (1993), Analysing innovation output counts: The US experience, In New Concepts in Innovation Output Measurement (Eds, Kleinknecht, A. and Bain, D.) St. Martin's Press, Houndmills, Basingstoke and London, pp. 10-41.

Addison, J.T., Kraft, K. and Wagner, J. (1993), German Works Councils and Firm Performance, in: Kaufman, B.E., Kleiner, M.M., Employee Representation: Alternatives and Future Directions, Madison: Industrial Relations Research Association, 305-335.

Addison, J.T., Schnabel, C. and Wagner, J. (1996), German Works Councils, Profits, and Innovation, Kyklos, vol. 49, 555-582.

Addison, J.T., Schnabel, C. and Wagner, J. (2000), Non-union Representation in Germany, in B.C. Kaufman and D. Gittlieb, (eds.) Non-union Employee Representation, History, Contemporary Practice and Policy, Armonk, New York, London, England: M.E. Sharpe, 365-385.

Addison, J.T., Schnabel, C. and Wagner, J. (2001), Works Councils in Germany: Their Effects on Establishment Performance, Oxford Economic Paper, vol. 53, 659-694.

Addison, J.T. and Wagner, J. (1997), The Impact of German Works Councils on Profitability and Innovation: New Evidence from Micro Data, Jahrbücher für Nationalökonomie und Statistik, vol. 216, 1-20.

Aghion, P: and Howitt, P. (1998), Endogenous Growth Theory, MIT Press, Cambrideg, MA.

Alchian, A.A. (1984), Specificity, Specialization, and Coalitions, Journal of Institutional and Theoretical Economics, vol. 140, 34-49.

D’Asprement, C. and Jacquemin, A. (1988), Cooperative and Non-cooperative R\&D in Duopolies with Spillovers, American Economic Review, vol. 78, 1133-1137.

Akerlof, G.A. and Yellen, J.L. (1990), The Fair Wage-Effort Hypothesis and Unemployment, Quarterly Journal of Economics, vol. 60, 255-282.

Audretsch, D.B. (1995), Firm Profitability; Growth, and Innovation, Review of Industrial Organization, vol. 10, 579-588.

Barro, R. and Sala-i-Marin, X. (2004), Economic Growth, 2nd Edition, MIT Press, Cambridge, MA.

Baudry, M.; Dumont, B. (2006), Comparing Firms' Triadic Patent Applications Across Countries: Is There a Gap in Terms of R\&D Effort or a Gap in Terms of Performances?, Research Policy 35, 324-342.

Baumol, W.J., Panzar, J.C. and Willig, R.D. (1982), Contestable Markets and the Theory of Industry Structure, New York. 
Ben-Zion, U. (1984), The R\&D and investment decision and its relationship to the firm's market value: Some preliminary results, In $\mathrm{R} \& \mathrm{D}$, Patents and Productivity (Ed, Griliches, Z.) University of Chicago Press, Chicago and London, pp. 299-314.

Bertschek, I. (1995), Product and Process Innovation as a Response to Increasing Imports and Foreign Direct Investment, The Journal of Industrial Economics vol. 43(4), 341-357.

Blundell, R., Griffith, R. and van Reenen, J. (1999), Market Share, Market Value and Innovation in a Panel of British Manufacturing Firms, Review of Economic Studies, vol. 66, 529-554.

Binmore, K., Rubinstein, A. and Wolinsky A. (1986), The Nash Bargaining Solution in Economic Modeling, Rand Journal of Economics, vol. 17, 176-188.

Booth, A.L. (1995), The Economics of the Trade Union, Cambridge: Cambridge University Press.

Booth, L.A. and Chatterji, M. (1995), Union Membership and Wage Bargaining When Membership is not Compulsory, Economic Journal, vol. 105, 345-360.

Bound, J., Cummins, C., Griliches, Z., Hall, B.H. and Jaffe, A. (1984), Who Does R and D and Who Patents in Zvi Griliches [Eds.]: R\&D, Patents, and Productivity, Chicago, University of Chicago Press.

Bughin, J. (1995), Unions and Strategic Managerial Incentives, Economics Letters, vol. 47, 95-100.

Cameron, A. and Trivedi, P. (1990), Regression Based Tests for Overdispersion in the Poisson Model, Journal of Econometrics, vol. 46, 347-364.

Chamberlain, G., (1992), Comment: Sequential Moment Restrictions in Panel Data, Journal of Business and Economic Statistics, vol. 10, 20-26.

Cincera, M. (1997), Patents, R\&D and Technological Spillovers at the Firm Level: Some Evidence from Econometric Count Models for Panel Data, Journal of Applied Econometrics, Vol. 12, p. 265-280.

Cohen, W.M. and Levin, R.C. (1989), Empirical Studies of Innovation and Market Structure, in: Schmalensee, R. und Willig, R.D. [Eds.], Handbook of Industrial Organization, Vol. II, Amsterdam: North Holland.

Cohen, Wesley M., Nelson, Richard R. and Walsh, John P. (2000), Protecting their Intellectual Assets: Appropriability Conditions and Why U.S. Manufacturing Firms Patent (or Not), NBER Working Paper No. 7552.

Commission Co-determination (1999), Participation and New enterprise Culture - Balance and Perspective, Hans-Böckler-Stiftung [eds.], Verlag Bertelsmann Stiftung, 2nd Edition.

Conolly, R. Hirsch, B. and Hirschey, M. (1986), Union Rent Seeking, Intangible Capital and the Market Value of the Firm, Review of Economics and Statistics, vol. 68, 567-577. 
Crépon, B. and Duguet, E. (1997a), Estimating the Innovation Function from Patent Numbers: GMM on Count Data Panel, Journal of Applied Econometrics, Vol. 12, p. 243-263.

Crépon, B. and Duguet, E. (1997b), Research and Development, Competition, and Innovation: Pseudo Maximum Likelihood and Simulated Maximum Likelihood Methods, Applied to Count Data Models with Heterogeneity, Journal of Econometrics, Vol. 79, p. 355-378.

Crépon, B., Duguet, E. and Mairesse, J. (1995), Research, Innovation, and Productivity: An Econometric Analysis at the Firm Level, National Bureau of Economic Research Working Paper: 6696.

Czarnitzki, D. and Kraft, K. (2008), On the Profitability of Innovative Assets, Applied Economics , vol. 40(21), 2721-2734.

De Bondt, R. and Henriques, I. (1995), Strategic Investment with Asymmetric Spillovers, Canadian Journal of Economics, vol. 28, 656-674.

Dowrick, S. (1989), Union-Oligopoly Bargaining, Economic Journal, vol. 99, 1123 -1142.

Dowrick, S. (1990), The Relative Profitability of Nash-Bargaining on the Labor Demand Curve or the Contract Curve, Economics Letter, vol. 33, 121-125.

Fallick, B.C. and Hassett, K.A. (1999), Investment and Union Certification, Journal of Labor Economics, vol. 17, 570-582.

Fershtman, C. (1985), International Organizations and Managerial Incentives as Strategic Variables in Competitive Environment, International Journal of Industrial Organization, vol. 3, 245-253.

Finegold, D. and Soscice, D. (1988), The Failure of Training in Britain: Analysis and Prescription, Oxford Review of Economic Policy, vol. 4, 21-53.

Fischer, Th. M. and Beckmann, S. (2007), Die Informationsversorgung der Mitglieder des Aufsichtsrates - Ergebnisse einer empirischen Studie deutscher börsennotierter Aktiengesellschaften, online-report, Nuernberg.

FitzRoy, F.R. and Kraft, K. (1985), Unionization, Wages and Efficiency, Kyklos, vol. 38, 537-554.

FitzRoy, F.R. and Kraft, K. (1987), Efficiency and Internal Organization: Works Councils in West German firms, Economica, vol. 54, 493-504.

FitzRoy, F.R. and Kraft, K. (1990), Innovation, Rent Sharing and the Organization of Labor in the Federal Republic of Germany, Small Business Economics, vol. 2, 95-103.

FitzRoy, F.R. and Kraft, K. (1993), Economic Effects of Co-Determination, Scandinavian Journal of Economics, vol. 95, 365-375.

FitzRoy, F.R: and Kraft, K. (2005), Co-determination, Efficiency and Productivity, British Journal of Industrial Orgainization, vol. 43, 233-247. 
Foltz, J., Bradford, B and Kwansoo, K. (2000), Universities and Agricultural Biotechnology Patent Production, Agribusiness, Vol.16, 82-95.

Freeman, R.B. and Lazear, E.P. (1995), An Economic Analysis of Works Councils”, in: Rogers, J. und Streeck, W., Works Councils - Consultation, Representation, and Cooperation in Industrial Relations, Chicago: University of Chicago Press, 27-52.

Furubotn, E.G. (1978), The Economic Consequences of Codetermination on the Rate and Sources of Private Investment, in: S. Pejovic (ed.) The Codetermination Movement in the West. Labor Participation in the Management of Business Firms, Lexington, MA: Lexington Books, 131-167.

Galbraith, J.K. (1952), American Capitalism - The Concept of Countervailing Power, Boston.

Gerum, E. (2007), Das deutsche Corporate Governance-System: Eine empirische Untersuchung, Stuttgart: Schäffer-Poeschel.

Gorton, G. and Schmid, F. (2000), Class Struggle Inside the Firm: A Study of German Codetermination, NBER Working Paper 7945.

Gorton, G. and Schmid, F. (2004), Capital, Labor, and the Firm: A Study of German Codetermination, Journal of the European Economic Association, vol. 2, 863-905.

Grabowski, H. G. and Mueller, D. C. (1978), Industrial Research and Development, Intangible Capital Stocks and Firm Profit Rates, Bell Journal of Economics, 9, 328-343.

Granero, L.M. (2006), Codetermination, R\&D, and Employment, Journal of Institutional and Theoretical Economics, vol. 162, 309-328.

Greene, W.H. (1994), Accounting for Excess Zero and Sample Selection in Poisson and Negative Binomial Regression Models, Working Paper, Stern School of Business, NYU EC-94-10.

Greene, W.H. (2000), Econometric Analysis, $4^{\text {th }}$ Ed., Upper Saddle River: Prentice Hall Inc.

Griliches, Z., Pakes, A., and Hall, B.H. (1986), The Value of Patents as Indicators of Inventive Activity, NBER Working Paper, No. 2083, Cambridge, MA: National Bureau of Economic Research.

Griliches, Z. (1990), Patent Statistics as Economic Indicators: A Survey, Journal of Economic Literature, Vol. 28, No. 4, pp. 1661-1707.

Griliches, Z. (1986), Productivity, R \& D, and Basic Research at the Firm Level in the 1970s, American Economic Review, 76, 141-154.

Griliches, Z., Pakes, A., and Hall, B.H. (1986), The Value of Patents as Indicators of Inventive Activity, NBER Working Paper, No. 2083, Cambridge, MA: National Bureau of Economic Research.

Griliches, Z. (1995), R\&D and Productivity: Econometric Results and Measurement Issues, In Handbook of the Economics of Innovation and Technological Change (Ed, Stoneman, P.) Blackwell, Oxford, UK and Cambridge, Mass., pp. 52-89. 
Grout, P.A. (1984), Investment and Wages in the Absence of Binding Contracts, Econometrica, vol. 52, 449-460.

Hall, B.H., Hausman, J.A. and Griliches, Z. (1986), Patents and R and D: Is There a Lag, International Economic Review, vol. 27, pp. 265-283.

Hall, B.H., Jaffe, A. and Trajtenberg, M. (2005), Market Value and Patent Citations, Rand Journal of Economics, vol. 36, 16-38.

Hall, B.H., Thoma, G. and Torrisi, S. (2007), The Market Value of Patents and R\&D: Evidence from European Firms, NBER Working Paper No. 13426.

Hall, B.H. and Ziedonis, R.H. (2001), The Patent Paradox Revisited: an Empirical Study of Patenting in the U.S. Semiconductor Industry, 1979-1995, RAND Journal of Economics, Vol. 32, No. 1, pp. 101-128.

Hansen, J.A. (1992), Innovation, Firm Size, and Firm Age, Small Business Economics, vol. 4, 37-44.

Hausman, J., Hall, B. and Griliches, Z. (1984), Economic Models for Count Data with an Application to the Patents-R\&D Relationship, Econometrica, vol. 52, 909-938.

Henriques, I. (1990), Cooperative and Noncooperative R\&D in Duopoly with Spillovers: Comment, American Economic Review, vol. 80, 638.640.

Hirschey, R.C. and Caves, R.E. (1981), Research and Transfer of Technology by Multinational Enterprises, Oxford Bulletin of Economics and Statistics, vol. 43, 115130.

IG Metall (2003), Die Innovation der Innovationspolitik, Frankfurt a.M.

Jensen, M.C. and Meckling, W.H. (1979), Rights and Production Functions: An Application to Labor-managed Firms and Co-determination, Journal of Business, vol. 52, 469-506.

Junkes, J. and Sadowski, D. (1999), Mitbestimmung im Aufsichtsrat, in: Frick, B., Kluge, N. und Streeck, W. [Eds.], Die wirtschaftlichen Folgen der Mitbestimmung, Frankfurt/Main: Campus Verlag.

Jürgens, U. and Lippert, I. (2005), Kommunikation und Wissen im Aufsichtsrat Vorrausserttzungen und Kriterien guter Aufsischtsratarbeit aus der Sichtweise leitender Angestellten, WZB-Discussion Paper 2005-301.

Kamien, M.I. and Schwartz, N.L. (1982), Market Structure and Innovation, Cambridge.

Kim, Y.; Marschke, G. (2004), Accounting for the Recent Surge in U.S. Patenting: Changes in R\&D Expenditures, Patent Yields, and the High Tech Sector. Economics of Innovation and New Technologie 13 (6), 543-558.

Kraft, K. (1989), Market Structure, Firm Characteristics and Innovative Activity, in: Journal of Industrial Economics, vol. 37, 329-336.

Kraft, K. (1998), The Co-determined Firm in Oligopoly, in: Economics Letters, vol. 61, 195201. 
Kraft, K. (2001), Co-determination as a Strategic Advantage?, in: International Journal of Industrial Organization, vol. 19, 543-566.

Kraft, K. and Stank, J. (2004), Die Auswirkungen der gesetzlichen Mitbestimmung auf die Innovationsaktivitäten deutscher Unternehmen, in: Schmollers Jahrbuch - Zeitschrift für Wirtschafts- und Sozialwissenschaften/ Journal of Applied Social Sciences Studies, vol. 124, 421-449.

Licht, G. and Zoz, K. (1998), Patents and R\&D: An Econometric Investigation Using Applications for German, European and US Patents by German Companies, Annales D’Économie et de Statistique, No. 49/50.

Mansfield, E., Romeo, A. and Wagner, S. (1979), Foreign Trade and U.S. Research and Development, Review of Economics and Statistics, vol. 61, 49-57.

McDonald, I.M. and Solow, R.M: (1981), Wage Bargaining and Employment, American Economic Review, vol. 71, 896-908.

Meliciani, V. (2000), The Relationship Between R\&D, Investment and Patents: A Panel Data Analysis, Applied Economics 32, 1429-1437.

Menezes-Filho, N., Ulph, D. and van Reenen, J. (1998), The Determination of R\&D: Empirical Evidence on the Role of Unions, European Economic Review, vol. 42, 919930.

Möller, I. (2000), Produktivitätswirkung von Mitarbeiterbeteiligung, in: Mitteilungen aus der Arbeitsmarkt- und Berufsforschung, vol. 33, S. 565-582.

Moulton, B.R. (1986), Random Group Effects and the Precision of Regression Estimates, Journal of Econometrics, vol. 32, 385-397.

Moulton, B.R. (1990), An Illustration of a Pitfall in Estimating the Effects of Aggregate Variables on Micro Units, Review of Economics and Statistics, vol. 72, 334-338.

Hansen, J.A. (1992), Innovation, Firm Size, and Firm Age, Small Business Economics, vol. 4, 37-44.

Mueller, Dennis C. (1966), Patents, Research and Development, and the Measurement of Inventive Activity, The Journal of Industrial Economics, Vol. 15, No. 1, pp. 26-37.

Mullahey, J. (1986), Specification and Testing of Some Modified Count Data Models, Journal of Econometrics, vol. 33, 341-365.

Niedenhoff, H.U. (1997), Mitbestimmung in der Bundesrepublik Deutschland, 11. Auflage, Köln: Deutscher Instituts-Verlag.

Pakes, A. and Griliches, Z. (1980), Patents and R\&D at the Firm Level: A First Report, Economics Letters, Vol. 5, pp. 377-381.

Pothoff, E. and Trescher, K. (1993), Das Aufsichtsratsmitglied, Stuttgart: Schäffer-Poeschel Publishing Company. 
Ravenscraft, D. and Scherer, F.M. (1982), The Lag Structure of Returns to Research and Development, Applied Economics, vol. 14, 603-620

Schnabel, C. and Wagner, J. (1992), Unions and Innovation: Evidence from German Micro Data, Economic Letters, vol. 39, 369-373.

Scherer, Frederic M. (1965), Firm Size, Market Structure, Opportunity and the Output of Patented Inventions, American Economic Review, Vol. 55, pp. 1097-1125.

Schmookler, J. (1966), Invention and Economic Growth, Harvard University Press, Cambridge.

Schumpeter, J.A. (1942), Capitalism, Socialism and Democracy, New York.

Sick, S., Kösterl, R. amd Mielke, B.K. (2005), Die Geschäftsordnung des Aufsichtsrats, Düsseldorf: Hans-Böckler-Foundation.

Smith, S.C. (1991), On the Economic Rationale for Co-Determination Law, Journal of Economic Behavior and Organization, vol. 16, 261-281.

Suzumura, K. (1992), Cooperative and Noncooperative R\&D in an Oligopoly with Spillovers, American Economic Review, vol. 54, 157-167.

Svejnar, J. (1982), Codetermination and productivity: Empirical evidence frome the Federal Republic of Germany, in: Jones, D. und Svejnar, J., Participatory and Self Managed Firm, Chaper 10, Heath, Lexington MA, 199-212.

Theisen, M.R. (1996), Grundsätze einer ordnungsmäßigen Information des Aufsichtsrats, Stuttgart: Schäffer-Poeschel.

Vuong, Q.H. (1989), Likelihood Ratio Tests for Model Selection and Non-Nested Hypotheses, Econometrica, vol. 57, 307-333.

Weizsäcker, von, C.C. (1984), Was leistet die Property Rights Theorie für aktuelle wirtschaftspolitische Fragen?, in: Neumann, M.: Ansprüche, Eigentums- und Verfügungsrechte, Duncker \& Humblot, Berlin, 123-152.

Wooldridge, J.M., (1997), Multiplicative Panel Data Models Without the Strict Exogeneity Assumption, Econometric Theory, vol. 13, 667-678.

Wooldridge, J.M., (2002), Econometric Analysis of Cross Section and Panel Data, MIT Press: Cambridge, Mass., London, England.

Zimmermann, K.F. and Schwalbach, J. (1991), Determinanten der Patentaktivität, IfoStudien, vol. 37, 201-227. 